\title{
Pemantauan Penggunaan Media Sosial Twitter Menggunakan Social Network Analysis dalam Melihat Politik Programatik pada Kampanye Pilkada Kota Depok Tahun 2020
}

\section{The Observation of Social Media Twitter Utilization using Social Network Analysis on Viewing Politic Programmatics in the 2020 Depok City Head Regional Election Campaign}

\author{
Wildhan Khalyubi ${ }^{1}$ \\ Christian Deswinta Bangun ${ }^{2}$ \\ Muhammad Rifqi Romadhona ${ }^{3}$ \\ Fikri Ardiyansyah ${ }^{4}$ \\ Universitas Indonesia ${ }^{1,2,4}$ \\ Gedung B (Tapi Omas Ihromi) Lt. 2 FISIP Universitas Indonesia, Depok, Jawa Barat \\ Universitas Pertahanan ${ }^{3}$ \\ Kawasan IPSC Sentul, Sukahati, Citereup, Bogor, Jawa Barat 16810 \\ E-mail: \\ wildhan.khalyub@gmail.com \\ deswintachristian@gmail.com \\ mrifairomadhona@gmail.com \\ fikri.ardiyansyah@ui.ac.id
}

\begin{abstract}
This research aims to explain the observation result of social media Twitter utilization on programmatic politics campaign in each candidate pairs as the winning attempt on 2020 regional head election in Depok City. Two candidate pairs are contesting on 2020 regional head election in Depok City. The number 1 candidate pair is Pradi Supriatna and Afifah Alia, carried by The Coalition of Depok Rises. Meanwhile, candidate pair number 2 is Mohammad Idris and Imam Budi Hartono, carried by the Coalition of the Ordered, Fair, and Prosperous. This research is qualitative research on a campaign about the campaign activities which viewed through the programmatic politics campaign of each candidate pair's Twitter account. The data collection technique in this research uses Social Network Analysis (SNA) on Twitter accounts that represent each candidate pair. Those accounts are such as @pradi_afifah and @idrisimam2020. This research also integrates Andreas Jungherr's perception of social media function on the campaign and Bardhan \& Mookherjee's perception of programmatic politics. Both perceptions intended to look social media function on doing programmatic politics campaign each candidate pairs. The findings of this research are that each candidate pairs enable social media Twitter as a programmatic politics campaign that offers the policy of various problems in Depok City.
\end{abstract}

Keywords: programmatic politics; local election; depok city; twitter; social network analysis

\section{Abstrak}

Penelitian ini bertujuan untuk menjelaskan hasil pemantauan penggunaan media sosial Twitter dalam melihat kampanye politik programatik setiap pasangan calon sebagai salah satu upaya pemenangan pada penyelenggaraan Pemilihan Kepala Daerah (Pilkada) Kota Depok Tahun 2020. Terdapat dua 
pasangan calon yang berkontestasi pada Pilkada Kota Depok Tahun 2020. Pasangan nomor urut 1 yakni Pradi Supriatna dan Afifah Alia diusung oleh Koalisi Depok Bangkit. Sementara itu pasangan calon nomor urut 2 yakni Mohammad Idris dan Imam Budi Hartono diusung oleh Koalisi Tertata Adil Sejahtera. Penelitian ini merupakan penelitian kualitatif mengenai aktivitas kampanye yang dilihat melalui kampanye politik programatik masing-masing akun pasangan calon di media sosial Twitter. Adapun teknik pengumpulan data dalam penelitian ini menggunakan Social Network Analysis (SNA) pada akun media sosial Twitter yang merepresentasikan masing-masing pasangan calon yakni akun @pradi_afifah dan akun @idrisimam2020. Penelitian ini memadukan pandangan Andreas Jungherr mengenai fungsi penggunaan media sosial dalam berkampanye dan pandangan Bardhan \& Mookherjee mengenai politik programatik. Kedua pandangan tersebut dimaksudkan untuk melihat fungsi media sosial dalam melakukan kampanye politik programatik setiap pasangan calon. Temuan dari penelitian ini adalah setiap kandidat dapat memfungsikan media sosial Twitter sebagai sarana kampanye politik programatik yang menawarkan kebijakan atas berbagai persoalan di Kota Depok.

Kata Kunci: Politik Programatik; Pilkada; Kota Depok; Twitter; Social Network Analysis

\section{Pendahuluan}

Mewabahnya pandemi Covid-19 di Indonesia berpengaruh pada segala proses agenda pemilihan kepala daerah (pilkada) secara serentak. Covid-19 dapat dikatakan sebagai pandemi karena adanya virus sebagai organisme yang dapat menular terhadap orang yang tidak memiliki kekebalan tubuh yang cukup, sehingga penularan tersebut menyebabkan penyakit yang dapat dikatakan berbahaya (Rinaldi \& Yuniasanti, 2020). Munculnya Covid-19 menjadi sebuah pandemi dinilai cukup berdampak terhadap penyelenggaraan pemilihan kepala daerah dikarenakan dapat mengubah segala tahapan dan proses dalam agenda pemilihan. Tahapan dan proses agenda pemilihan tersebut biasanya dilakukan dengan adanya interaksi langsung sesama warga negara, termasuk interaksi antara pemilih dan juga kandidat.

Akan tetapi dikarenakan adanya pandemi Covid-19, para stakeholder penyelenggara pemilihan diharuskan merumuskan sebuah pengaturan pemilihan dengan memperhatikan keamanan dan keselamatan seluruh pihak dalam penyelenggaraan pilkada 2020.
Maka dari itu, dibutuhkan klausul pengaturan terutama pada aturan teknis peraturan Komisi Pemilihan Umum (PKPU) dan juga peraturan Badan Pengawas Pemilu (Perbawaslu) yang disesuaikan dengan kondisi pandemi Covid-19 seperti penerapan protokol kesehatan, jaga jarak, atau pengaturan yang meliputi berbagai tindakan yang bersifat adaptif dalam setiap proses dan tahapan pilkada (Husnulwati, 2021).

Lebih lanjut, perubahan aturan dalam agenda pemilihan tersebut juga salah satunya diwujudkan dengan adanya pengaturan baru pada tahapan kampanye. Kampanye dinilai begitu krusial karena merupakan sebuah proses yang meliputi kegiatan berupa komunikasi secara individu atau terlembaga dengan tujuan untuk menciptakan suatu efek tertentu (Maulidika \& Agung, 2014). Perubahan aturan kampanye yang bersifat adaptif dengan kondisi pandemi Covid-19 dijelaskan dalam aturan teknis PKPU No. 13 Tahun 2020 sebagai pengganti PKPU No. 6 Tahun 2020 yang dimana kampanye salah satunya membatasi pertemuan tatap muka sebanyak 50 orang dan wajib protokol 
kesehatan serta menganjurkan menggunakan media sosial.

Pengaturan mengenai kampanye di media sosial juga didasari dua alasan dalam penggunaannya. Pertama, adanya jaringan informasi yang tidak mudah dikendalikan oleh negara serta media sosial sebagai alat koordinasi yang sudah tertanam dalam jaringan pertemanan dan keluarga dapat memudahkan proses komunikasi politik. Kedua, media sosial cenderung gratis dan ekonomis sehingga dapat diakses secara luas oleh seluruh kelas ekonomi (Nurjaman, 2020).

Adapun penggunaan media sosial sebagai alat berkampanye diatur lebih lanjut mengenai tenggat waktu yang telah ditetapkan. Pengaturan tersebut tercantum dalam PKPU Nomor 5 Tahun 2020 tentang Perubahan Ketiga atas Peraturan Komisi Pemilihan Umum Nomor 15 Tahun 2019 tentang Tahapan, Program dan Jadwal Penyelenggaraan Pemilihan Gubernur dan Wakil Gubernur, Bupati, dan Wakil Bupati, dan/atau Wali Kota dan Wakil Wali Kota Tahun 2020 bahwasannya kampanye sebagaimana umumnya termasuk kampanye di media sosial dapat dilakukan selama 71 hari yakni tepatnya pada tanggal 26 September hingga 05 Desember 2020.

Pembahasan mengenai bentuk kampanye politik menggunakan media sosial dibahas oleh beberapa pandangan sebelumnya. Misalkan Ardha (2014) menjelaskan bahwa kampanye di media sosial merupakan wadah untuk menyebarkan ide-ide dan memudahkan interaksi antar para pengguna. Selain itu, kampanye politik di media sosial juga merupakan kampanye yang bukan seperti pada umumnya secara tradisional. Secara realitasnya, kampanye di media sosial tidak dapat terlalu berpengaruh pada bentuk mobilisasi masa. Kemudian, pandangan Setiadi (2016) menjelaskan bahwa penggunaan media sosial dalam kampanye politik mempermudah para aktor politik untuk mendiferensiasikan diri dalam persaingan politik yang berbentuk informasi yang tak terbatas (borderless), kemudahan dalam membangun citra (image), dan juga melakukan political branding.

Berbeda dengan Lilleker \& KocMichalska (2017) yang menjelaskan bahwa penggunaan media sosial dalam berkampanye pada agenda pemilihan dapat menjadi insentif aktivitas-aktivitas politik lainnya. Media sosial menyediakan ruang untuk berkomunikasi secara luas, akan tetapi adanya motivasi intrinsik dari setiap individu sebagai penggunanya dapat mendorong terbentuknya partisipasi sipil. Secara tidak langsung pandangan ini menjelaskan bahwa kampanye yang dilakukan di media sosial juga dapat mempengaruhi pada bentuk partisipasi secara riil yang ditunjang dengan aktivitas politik organisasi kampanye setiap kandidat.

Pandangan Christiner B. Williams (2017) juga menjelaskan bahwa penggunaan media sosial telah menciptakan lingkungan komunikasi yang lebih besar, lebih cepat, dan lebih heterogen dari sebelumnya. Ini tentunya memberikan bentuk eksplorasi narasi di media sosial serta dampak yang muncul melalui pemasaran politik dan interaksi yang mendasari hubungan antara kandidat dan pemilih. Pandangan ini menjelaskan 
bahwa media sosial dapat dijadikan alat berkampanye mengenai program dan membangun citra diri para kandidat tersebut.

Beberapa pandangan penggunaan media sosial dalam berkampanye tersebut memiliki korelasi dengan sebuah pemasaran program kebijakan yang dicanangkan baik itu oleh organisasi kampanye politik (dalam hal ini adalah partai politik atau gabungan partai politik), maupun oleh kandidat yang mencalonkan diri pada kontestasi pemilihan. Sehingga penggunaan media sosial dengan memperkenalkan programatik politik yang berupa wacana kebijakan dipandang sebagai salah satu upaya atau strategi para aktor politik untuk mempengaruhi para audiens di media sosial.

Diskursus mengenai politik programatik kerap disandingkan sebagai antithesis dari politik patronase dan klientelisme yang selama ini dilakukan oleh para aktor politik. Politik programatik banyak didukung dengan kampanye kebijakan yang dilakukan oleh partai politik maupun kandidat politik. Sehingga dalam memandang politik programatik pada umumnya sebagai bagian dari strategi dan tindakan politik yang dapat dijalankan oleh aktor politik baik itu partai politik maupun kandidat. Pembahasan partai politik berada pada sepanjang spektrum strategi politik yang luas antara 'terprogram' seperti program kebijakan yang ditawarkan melalui konstruksi isu kesehatan, pendidikan, budaya dan lain sebagainya. Begitu pun dengan strategi yang dapat dikatakan tidak 'terprogram' seperti personalisme, populisme, klientelisme, patronase, etnisitas, atau identitas lainnya (Cheeseman et al., 2014).

Seruan programatik untuk mendapatkan dukungan menarik perhatian pemilih terhadap kebijakan dan kemungkinan sebuah partai mengimplementasikan programnya (Herbert Kitschelt, 1995). Herbert Kitschelt dan Steven Wilkinson mengamati bahwa manfaat dari kampanye politik yang terprogram ditawarkan dengan cara yang tidak bergantung, jadi manfaat diberikan kepada individu terlepas dari apakah mereka memilih pihak yang mencetuskan program tersebut (2007, hlm 22). Politik programatik tidak jauh dari sebuah sistem yang terprogram ketika partai-partai di dalamnya secara dominan menghasilkan kebijakan, memobilisasi dukungan dan memerintah atas dasar posisi ideologis yang konsisten dan koheren. Agar partai menjadi terprogram, mereka harus memobilisasi dukungan berdasarkan kebijakan mereka, memiliki struktur internal yang menjaga komitmen pemimpin partai terhadap kebijakan tersebut (Cheeseman et al., 2014).

Politik programatik terjadi di India tepatnya di negara bagian India Selatan, Tamil Nadu. Kendati politik klientelisme dan patronase masih terjadi pada pemilihan di India tersebut, akan tetapi para partai politik juga menawarkan kebijakan terprogram yang menjadi daya tarik. Dalam kurun waktu 6 tahun terakhir, politik programatik menjadi sebuah arena pertarungan pragmatisme para aktor politik di tengah situasi kompetisi partai politik yang ketat. Misalnya, dorongan dari para pemimpin partai yang mencari keuntungan dalam sistem kepartaian yang 
kompetitif. Skema makan siang yang jadwalnya diperluas merupakan inisiatif pribadi dari M. G. Ramachandran (MGR) sebagai pimpinan the All-India Anna Dravida Munnetra Kazhagam (AIADMK) yang ingin menerapkan skema yang memenuhi keinginannya untuk dilihat sebagai pelindung perempuan, orang miskin, dan rentan (Wyatt, 2013).

Sementara itu, politik programatik yang direalisasikan dalam kampanye pemilu juga mengaitkan dengan sistem pemilu single non-Transferable Vote (SNTV) di Jepang. Kampanye politik programatik meningkat seiring dengan persaingan partai secara internal. Sehingga para politisi dapat membangun janji-janji kampanyenya secara programatik melalui pencanangan kebijakan. Pencanangan kebijakan ini disajikan dalam manifesto kandidat partai politik di Jepang pasca reformasi pemilu. Ini mengartikan bahwa politik programatik juga tumbuh dari para kandidat yang dirancang untuk dipahami oleh pemilih melalui kebijakan politik yang dibuatnya (Catalinac, 2015).

Politik programatik juga terealisasi di Indonesia pada pemilihan kepala daerah Kulon Progo tahun 2017. Misalnya, dalam Mas'udi \& Kurniawan (2017) dijelaskan bahwa pemilu di Kulon Progo pada tahun 2017 tersebut memberikan konfirmasi kuat mengenai politic delivery dapat menjadi strategi kemenangan di kabupaten yang relatif miskin di Indonesia. Politik programatik dalam fenomena ini juga didukung dengan adanya legitimasi elektoral yang kuat sebagian besar berasal dari implementasi kebijakan sosial oleh petahana termasuk di bidang kesehatan dan pendidikan. Politik programatik ini juga secara tidak langsung merusak pola politik patronase yang kerap dilakukan dalam kontestasi pemilu. Maka dari itu, penelitian ini memunculkan pertanyaan terkait bagaimana kampanye politik programatik dapat dilakukan dengan menggunakan media sosial di Kota Depok?

Penulis mencoba melihat kampanye politik yang terprogram pada penyelenggaraan Pemilihan Kepala Daerah Kota Depok dengan memantau media Twitter melalui Social Network Analysis. Twitter dipilih karena merupakan ruang publik plural yang di dalamnya berisi ruangruang diskusi berbagai kelompok hingga membentuk ruang publiknya tersendiri (Hasfi et al., 2017). Terdapat dua pasangan calon yang berkontestasi pada Pilkada Kota Depok Tahun 2020. Pasangan nomor urut 1 yakni Pradi Supriatna sebagai calon Wali Kota Depok dan Afifah Alia sebagai calon Wakil Wali Kota Depok yang merepresentasikan Koalisi Depok Bangkit. Sementara itu pasangan calon nomor urut 2 yakni Mohammad Idris sebagai calon Wali Kota Depok dan Imam Budi Hartono sebagai calon Wakil Wali Kota Depok yang merepresentasikan Koalisi Tertata Adil Sejahtera.

Penulis memilih Kota Depok sebagai lokasi penelitian dikarenakan terdapat beberapa pertimbangan. Pertama, Kota Depok merupakan daerah yang terdapat kasus Covid-19 pertama di Indonesia dan salah satu daerah yang memiliki angka Covid-19 cukup tinggi di Jawa Barat. Kedua, Kota Depok juga merupakan salah satu daerah yang menggelar Pilkada di Jawa Barat selain Pangandaran, Tasikmalaya, Bandung, Sukabumi, Indramayu, Cianjur, dan Karawang. Beberapa alasan tersebut 
mendasari penulis untuk melihat kampanye programatik di media sosial beserta substansi narasinya pada penyelenggaraan Pilkada Kota Depok tahun 2020. Seiring dengan penggunaan media sosial dalam kontestasi pemilihan umum dan pemilihan kepala daerah, penelitian ini mencoba melengkapi beberapa pandangan diatas mengenai penggunaan media sosial dalam kampanye politik terutama dengan melihat narasi kampanye politik secara programatik sebagai bentuk upaya pemenangan dari masing-masing pasangan calon.

\section{Metode Penelitian}

Metode penelitian yang digunakan dalam penelitian ini adalah penelitian deskriptif kualitatif dengan membandingkan politik programatik pada setiap narasi kampanye pasangan calon. Pendekatan kualitatif dipilih karena digunakan untuk mengeksplorasi dan juga memahami berbagai makna yang terkandung baik itu dalam kelompok tertentu maupun individu yang berada dalam permasalahan sosial atau kemanusiaan (Creswell, 2016). Teknik pengumpulan data dalam penelitian ini menggunakan Social Network Analysis (SNA) Nvivo 12 Plus pada masing-masing akun media sosial Twitter pasangan calon.

Lebih lanjut, penulis melihat aktivitas kampanye politik pasangan calon pada tahapan kampanye di setiap minggunya dengan melihat kampanye politik programatik yang dinarasikan di media sosial Twitter. Kemudian dengan menggunakan Social Network Analysis (SNA) Nvivo 12 Plus, penulis mengklasifikasikan setiap narasi menjadi isu yang memuat politik programatik mengenai kebijakan yang akan dicanangkan apabila pasangan calon terpilih menjadi kepala daerah. Selain itu, penulis juga mendalami respon warga internet terhadap kampanye politik programatik yang dinarasikan setiap pasangan calon dengan mengacu pada indikator kerawanan pemilu di media sosial.

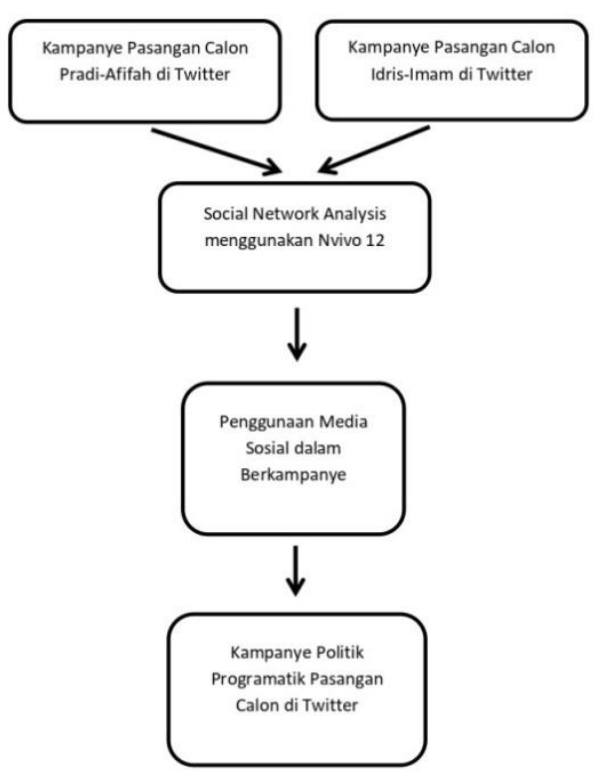

Gambar 1. Tahapan Penelitian

Social Network Analysis (SNA) itu sendiri merupakan studi yang mempelajari hubungan manusia dengan memanfaatkan pendekatan graph. Graph itu sendiri terbagi menjadi dua bagian yakni node yang dapat dikatakan sebagai representasi pengguna media sosial, dan edge yang dikatakan sebagai representasi relasi antar pengguna media sosial (Diana, 2017). Maka penggunaan SNA dalam penelitian ini adalah dengan melihat narasi dan interaksi yang tercipta dalam setiap postingan akun media sosial Twitter para pasangan calon. Sehingga melalui penggunaan media sosial twitter tersebut didapati sebuah 
kampanye politik programatik setiap pasangan calon.

\section{Kerangka Teori}

Penulis memilih teori kampanye di media sosial Andreas Jungherr (2016) dengan teori politik programatik Bardhan \& Mookherjee (2018) sebagai landasan dari penelitian ini. Sebelumnya pandangan mengenai kampanye terutama kampanye digital banyak diutarakan oleh para ahli. Misalnya Dan Nimmo (2010) menjelaskan bahwa kampanye merupakan proses bentuk penciptaan ulang dan pengalihan lambang yang dilakukan oleh individu maupun kelompok. Sementara itu Douglas Hagar, (2014) menjelaskan bahwa media sosial memiliki peranan penting terhadap keberhasilan politik. Hal ini dikarenakan adanya interaksi antara yang dipilih dengan yang akan memilih pada ajang penyelenggaraan pemilihan. Model kampanye dalam media sosial ini tidak dapat dilakukan dalam model kampanye secara tradisional.

Kedua pandangan tersebut di atas mengenai kampanye politik belum mengaitkan pada konteks penggunaan media sosial dalam berkampanye. Lebih lanjut, Andreas Jungherr (2016) yang menjelaskan empat fungsi secara holistik penggunaan media sosial dalam kampanye politik. Pertama, penggunaan media sosial berimplikasi pada rutinitas kinerja tim kampanye terutama dengan melihat konten kampanye yang diunggah dalam kurun waktu tertentu. Kedua, kampanye di media sosial juga menciptakan ruang informasi secara langsung kepada para pengguna. Terutama penggunaan media sosial dalam kampanye dapat mempengaruhi lingkungan komunikasi selama proses kampanye. Ketiga, kampanye di media sosial dapat digunakan untuk melakukan mobilisasi dan mengkoordinasikan para pemilih untuk memilih ke bilik suara. Keempat, adanya proses simbolik dengan menggunakan retorika tertentu guna menarik dukungan dari publik di dunia digital.

Sementara itu, teori politik programatik diadopsi melalui literatur Bardhan \& Mookherjee (2018) yang menjelaskan fenomena kampanye politik programatik sebagai alternatif dari bentuk klientelisme politik yang kerap menjadi bagian dalam kontestasi pemilu. Literatur Bardhan \& Mookherjee (2018) menunjukan fitur kebaruan dengan menawarkan pandangan kontras antara politik klientelisme dan politik programatik. Akan tetapi, dalam penelitian ini, penulis mencoba membatasi pandangan Bardhan \& Mookherjee (2018) tersebut sebatas pada bentuk politik programatik yang kerap dilakukan oleh para aktor politik.

Platform kebijakan dalam politik terprogram dapat dirancang oleh para kontestan politik untuk mempengaruhi dukungan politik di masa depan. Bardhan \& Mookherjee (2018) juga menjelaskan politik yang terprogram melibatkan kebijakan dengan aturan kelayakan yang didefinisikan dengan jelas berdasarkan karakteristik yang dapat diverifikasi dan diterima secara publik. Ini mengartikan kepada siapa negara akan melangsungkan programnya secara langsung sebagai perantara kepada publik dengan melalui tawaran formulasi (kebijakan).

Selain itu, pengaruh persaingan politik dapat melangsungkan bentuk tawaran 
politik yang terprogram melalui platform penawaran kebijakan dari setiap kontestan yang bersaing. Misalnya, para kandidat yang bersaing mengusulkan tawaran kebijakan yang berupa pajak penghasilan, jaminan sosial, dan tunjangan kesejahteraan yang mendefinisikan hak warga negara sebagai fungsi dari karakteristik yang nyata, yang secara efektif diberlakukan. Hal ini tentunya guna dapat diterima dan dipilih oleh publik melalui tawaran kebijakan tersebut.

Kedua teori tersebut menjadi dasar penulis untuk melihat penggunaan media sosial dalam melakukan kampanye politik programatik oleh masing-masing pasangan calon. Penulis mengintegrasikan pandangan Andreas Jungherr (2016) dan Bardhan \& Mookherjee (2018) guna melihat temuan dalam penelitian ini. Sebagaimana pandangan Andreas Jungherr (2016) mengenai empat fungsi penggunaan media sosial, maka kampanye politik programatik dapat dilihat melalui empat fungsi penggunaan media sosial dalam berkampanye. Pertama, penggunaan media sosial yang memuat rutinitas kampanye yang terprogramatik di media sosial dapat dilihat melalui seberapa banyak aktivitas kampanye pasangan calon di twitter. Kedua, kampanye yang menciptakan ruang informasi kepada para pengguna memungkinkan ruang informasi mengenai politik terprogram dalam bentuk tawaran kebijakan pasangan calon. Sehingga fungsi media sosial yang kedua ini menjadi acuan untuk melihat klasifikasi masing-masing tawaran program pada kampanye yang dinarasikan di media sosial oleh setiap pasangan calon.
Ketiga, fungsi kampanye programatik di media sosial dapat berpengaruh terhadap para pemilih untuk memilih pasangan calon tersebut. Sehingga fungsi ini dijadikan sebagai melihat implikasi kampanye politik programatik menggunakan media sosial Twitter terhadap perolehan suara pasangan calon. Keempat, sebagaimana fungsi kampanye di media sosial yang menjelaskan adanya proses simbolik dengan menggunakan retorika tertentu dalam menarik dukungan dari publik di dunia digital, maka penulis mencoba melihat narasi yang dijadikan sebagai simbol baik itu berupa tagar yang menjadi ajakan untuk memilih pasangan calon melalui media sosial Twitter.

\section{Hasil Pembahasan}

Penulis melakukan pemantauan terhadap masing-masing akun media sosial pasangan calon di media sosial Twitter dengan menggunakan Social Network Analysis (SNA) Nvivo 12 Plus. Ada pun akun media setiap pasangan calon ialah penulis memantau akun media sosial Twitter @pradi_afifah sebagai representasi kampanye politik pasangan calon nomor urut 1 yakni Pradi Supriatna dan Afifah Alia. Sementara itu akun media sosial Twitter @idrisimam2020 merupakan akun media sosial yang merepresentasikan pasangan calon nomor urut 2 yakni Mohammad Idris dan Imam Budi Hartono. Pada bagian pembahasan ini penulis menjelaskan lebih lanjut mengenai temuan yang berkaitan dengan fungsi media sosial dalam kampanye programatik oleh setiap pasangan calon. 


\section{a. Aktivitas Kampanye di Media Sosial}

Sebagaimana Andreas Jungherr (2016) menjelaskan bahwa salah satu fungsi media sosial adalah adanya rutinitas kinerja kampanye secara digital oleh pasangan calon. Maka dari itu, penulis mencoba melihat aktivitas kampanye di media sosial dengan menggunakan SNA Nvivo 12 Plus dalam bentuk timeline di setiap minggunya. Hal itu dijelaskan dalam grafik $\mathbf{1}$ dan grafik $\mathbf{2}$ yang merupakan timeline aktivitas kampanye politik programatik masing-masing akun Twitter pasangan calon baik itu akun @pradi_afifah maupun @idrisimam2020. Aktivitas tersebut dapat berupa unggahan, retweet, quote retweet, dan like di Twitter. Kendati pengaturan kampanye diatur dalam PKPU No. 5 Tahun 2020 yang dimulai pada tanggal 26 September hingga 05 Desember 2020, akan tetapi aktivitas kampanye politik programatik pasangan calon di media sosial sudah terlihat pada beberapa minggu sebelumnya. Lebih lanjut, aktivitas kampanye politik programatik di Twitter pasangan calon Pradi-Afifah ditunjukan oleh akun @pradi_afifah sebagaimana berikut:

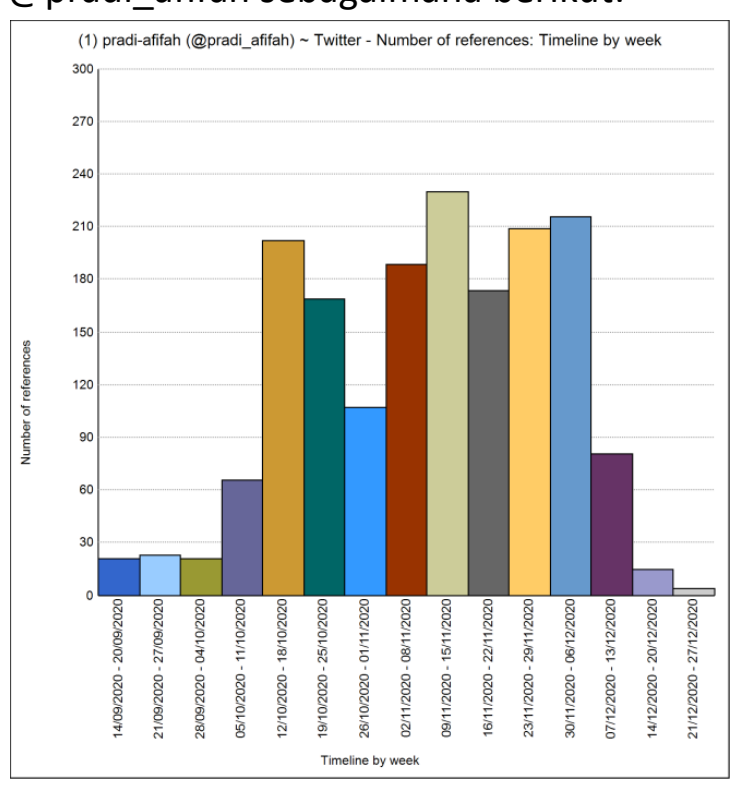

Grafik 1. Timeline Media Sosial PradiAfifah di Twitter

\section{Sumber: data diolah penulis}

Grafik 1 menjelaskan bahwa terdapat aktivitas akun @pradi_afifah yang dimulai pada tanggal 14 September 2020. Kemudian grafik tersebut menunjukan aktivitas yang mengalami kenaikan pada tanggal 05 Oktober 2020 dengan terdapat sekitar lebih dari 60 aktivitas di Twitter. Akun @pradi_afifah mengalami eskalasi aktivitas pada tanggal 09 September dengan terdapat 200 aktivitas di setiap minggunya. Pada menjelang hari tenang, aktivitas akun @pradi_afifah mengalami penurunan pada tanggal 07 Desember 2020 dengan hanya mencatatkan sekitar 80 aktivitas Twitter. Maka dari grafik 1 dapat disimpulkan bahwa akun @pradi_afifah dapat menjangkau capaian 100 aktivitas setiap minggunya hanya berada pada bulan Oktober dan November.

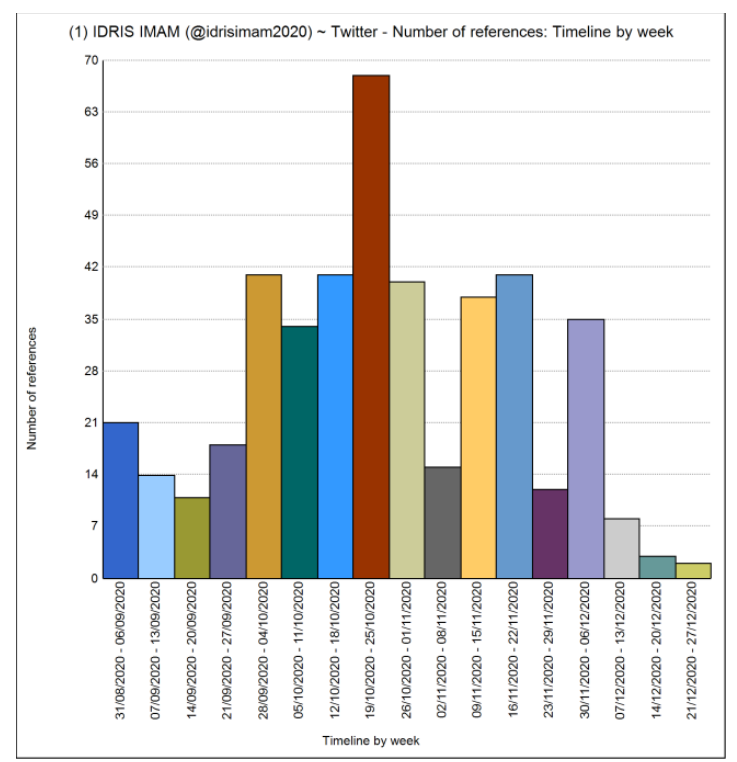

Grafik 2. Timeline Media Sosial Idris-Imam di Twitter

Sumber: data diolah penulis

Sedangkan aktivitas pasangan calon Idris-Imam yang ditunjukan dengan akun 
@idrisimam2020 menunjukan temuan yang berbeda dengan grafik 2. Kendati pengaturan kampanye baru dimulai pada tanggal 26 September 2020, akun @idrisimam2020 telah memulai aktivitas di media sosial beberapa minggu sebelumnya, termasuk dengan mulai menunjukan aktivitasnya pada tanggal 31 Agustus 2020 dengan 21 aktivitas Twitter. Kemudian, pada tanggal 28 September 2020 yang merupakan awal minggu dimulainya aktivitas kampanye, akun @idrisimam2020 mulai menunjukan kenaikan aktivitas sekitar 40 aktivitas di Twitter. Akun @idrisimam2020 berada pada tahapan eskalasi aktivitas pada tanggal 19 Oktober 2020 dengan mencatatkan aktivitas yang kurang dari 70 aktivitas akun. Lebih lanjut, hal yang sama dilakukan dengan akun pasangan calon Pradi-Afifah, akun @idrisimam2020 menunjukan penurunan menjelang dan tepat pada hari masa tenang yakni pada tanggal 07 Desember 2020 dengan hanya mencatatkan 8 aktivitas kampanye di Twitter. Pada grafik 2 didapati bahwa aktivitas akun @idrisimam2020 belum pernah mencapai 100 aktivitas sebagaimana dengan akun @pradi_afifah sebelumnya.

Rendahnya aktivitas akun Twitter @idrisimam2020 apabila dibandingkan dengan@akun@ @pradi_afifah memperlihatkan masing-masing bentuk rutinitas kerja tim pemenangan untuk mengunggah postingan atau membalas komentar di media sosial seperti yang dijelaskan oleh Andreas Jungherr (2016). Rutinitas kerja akun media sosial kampanye tersebut lebih lanjut menjelaskan daya tarik konten media sosial terhadap berbagai bentuk keterlibatan politik secara kognitif di dunia digital. Keterlibatan politik secara kognitif dapat mendorong warga internet untuk mencari informasi lebih hingga mengidentifikasi diri terhadap partai politik tertentu (Carreras, 2016). Keterlibatan politik dalam media sosial di antara kedua pasangan calon dapat disimpulkan bahwa pasangan calon Pradi-Afifah lebih aktif dalam hal berkampanye politik programatik dibandingkan dengan pasangan calon IdrisImam. Penjelasan tersebut juga didukung dengan temuan penulis menggunakan SNA Nvivo 12 Plus pada grafik 3 terkait sebaran narasi kampanye politik programatik di Twitter yang juga mencerminkan aktivitas akun media sosial sebagaimana dijelaskan berikut:

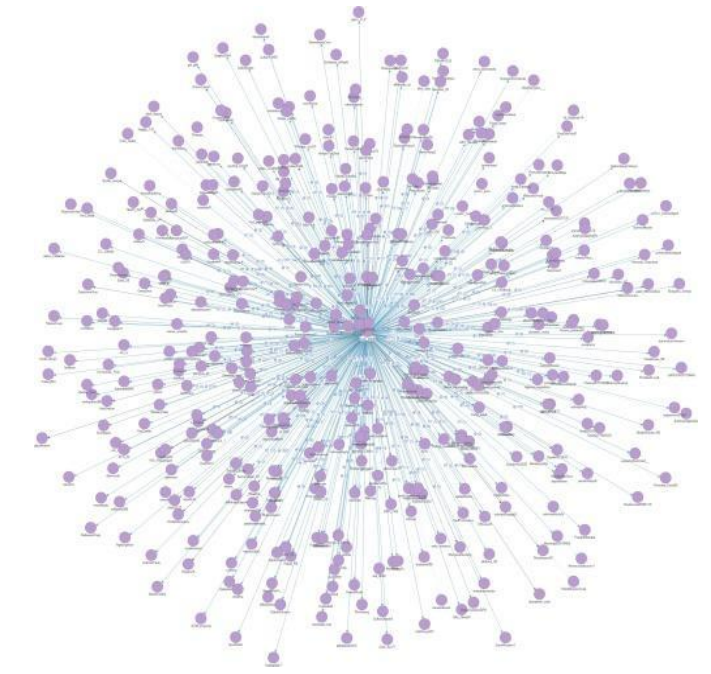

Grafik 3. Sebaran Narasi Pradi-Afifah yang Mencerminkan Aktivitas Kampanye di Twitter Sumber: data diolah penulis

Grafik 3 tersebut menjelaskan mengenai nodes atau akun yang membangun narasi percakapan di media sosial Twitter. Grafik tersebut menjelaskan bahwa nodes atau akun Twitter berjejaring satu sama lain yang berkaitan dengan nodes @pradi_afifah dalam membangun 
percakapan kampanye. Akun-akun media sosial pendukung pasangan calon PradiAfifah aktif menarasikan kandidatnya baik itu mengenai citra diri, program, visi, dan misi pasangan kandidat. Banyaknya akun yang membangun aktivitas percakapan tersebut dapat dijelaskan bahwa kampanye di media sosial Twitter merupakan sebuah hal yang memungkinkan seiring dengan adanya interaktivitas yang dapat dibangun melalui setiap penyampaian narasi politik.

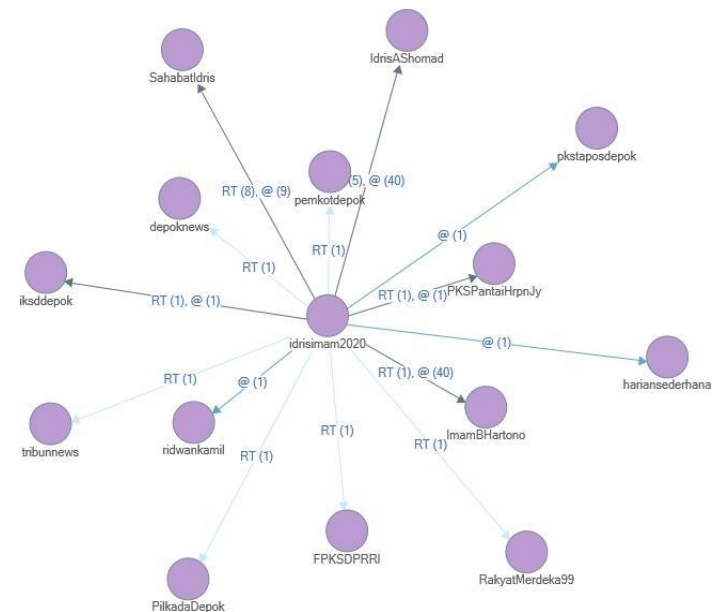

Grafik 4. Sebaran Narasi Idris-Imam yang Mencerminkan Aktivitas Kampanye di Twitter

Sumber: data diolah penulis

Sementara itu, aktivitas sebaran narasi kampanye politik programatik pasangan calon Idris-Imam dalam Grafik 4 dinilai masih kalah "ramai" dalam membangun narasi percakapan kampanye politik programatik dibanding dengan pasangan calon Pradi-Afifah. Tercatat hanya ada 15 nodes yang merepresentasikan akun media sosial Twitter yang saling terkait dengan akun @idrisimam2020 sebagai nodes induk dalam membangun narasi kampanye politik programatik di Twitter. Maka dari itu, hal ini dapat disimpulkan bahwa akun media sosial Twitter pasangan calon PradiAfifah dinilai lebih aktif dengan menunjukan rutinitas postingan yang lebih masif di setiap minggunya serta dapat membangun keterlibatan politik secara kognitif melalui interaksi dan rutinitas postingan kampanye politik programatik di media sosial Twitter. Ini tentunya menjawab pandangan Andreas Jungherr (2016) mengenai fungsi media sosial yang menggambarkan rutinitas kinerja kampanye secara digital dalam menarasikan sebuah kampanye politik programatik masing-masing pasangan calon.

\section{b. Kampanye Politik Programatik Pasangan Calon}

Salah satu fungsi penggunaan media sosial dalam berkampanye juga salah satunya guna menciptakan ruang informasi secara langsung kepada para pengguna (Jungherr, 2016). Terutama penggunaan media sosial dalam kampanye dapat menawarkan sebuah kebijakan sebagai bagian dari kampanye politik programatik masing-masing pasangan calon. Sebagaimana Bardhan \& Mookherjee (2018) menjelaskan bahwa platform kebijakan dalam sebuah kampanye politik adalah bagian dari upaya politik programatik yang ditawarkan kepada publik untuk dapat diterima sebagai upaya penuntasan persoalan oleh pasangan calon apabila terpilih pada agenda pemilihan. 


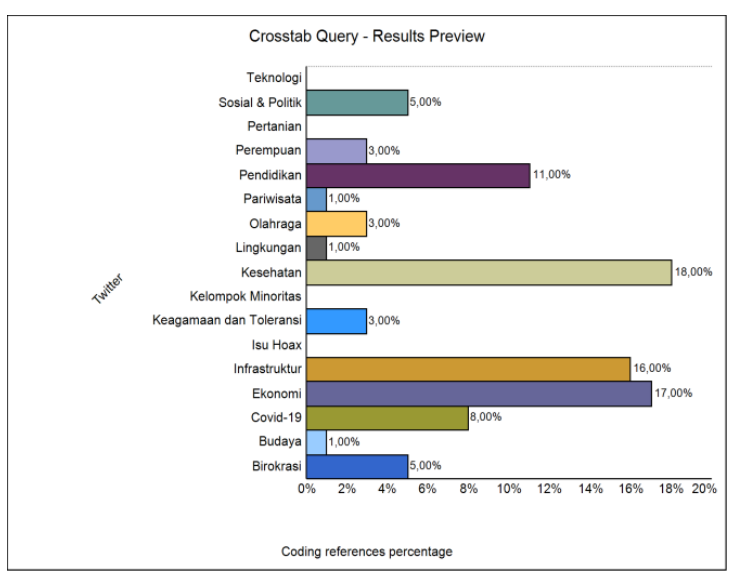

Grafik 3. Program Kampanye Pradi-Afifah di Media Sosial Twitter

Sumber: data diolah penulis

Terdapat orientasi program kampanye politik secara programatik yang selalu dinarasikan oleh kedua akun tersebut. Hal ini dijelaskan pada grafik 3 dan grafik 4 mengenai program kampanye kedua akun Twitter@ @pradi_afifah dan @idrisimam2020. Penjelasan dalam grafik 3 tersebut, menunjukan terkait program kampanye pasangan calon Pradi-Afifah yang kami peroleh dari Twitter melalui proses coding SNA Nvivo 12 Plus dengan melihat setiap narasi kampanye politik yang muncul dalam setiap postingan akun @pradi_afifah. Narasi kampanye politik yang bersifat programatik tersebut kemudian kami klasifikasikan ke dalam beberapa isu persoalan yang memang menjadi tawaran kebijakan pasangan calon tersebut.

Pada akun @pradi_afifah, isu mengenai kesehatan menempati persentase tertinggi dalam kampanye politik programatik di media sosial Twitter yakni sebesar $18 \%$. Tingginya isu kampanye yang dinarasikan tersebut dikarenakan adanya program kampanye mengenai tawaran kebijakan pelayanan berobat gratis menggunakan Kartu Tanda
Penduduk (KTP) (lihat Republika, 2020). Di urutan kedua disusul program kampanye mengenai ekonomi sebesar $17 \%$. Program kampanye ini berupa tawaran kebijakan mengenai pengembangan ekonomi pembukaan lapangan kerja yang disertai dengan program pelatihan UMKM serta kemudahan izin dalam membangun perekonomian di Kota Depok (lihat Media Indonesia, 2020). Program kampanye yang terakhir yakni program pembangunan infrastruktur sebesar $16 \%$. Isu program kampanye ini ditawarkan dengan adanya kebijakan serta janji Pradi-Afifah dalam menuntaskan kemacetan di Kota Depok dengan salah satunya memperlebar jalan raya (lihat Ayok Jakarta, 2020).

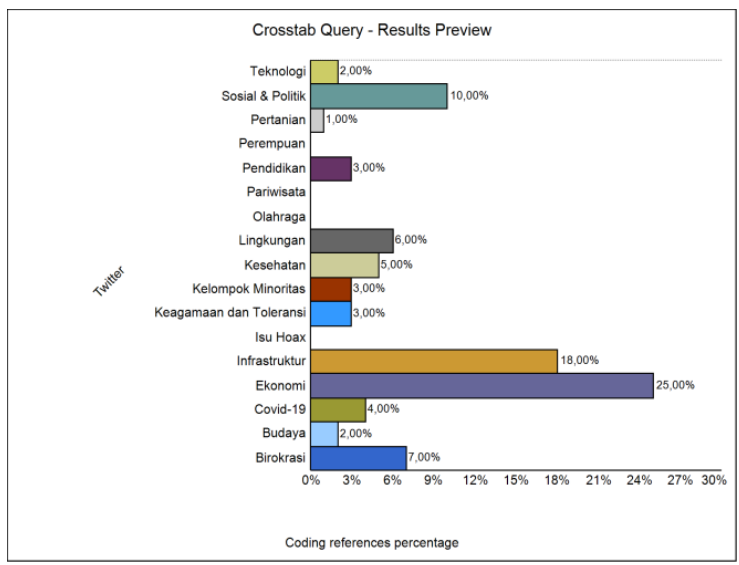

Grafik 4. Program Kampanye Idris-Imam di Media Sosial Twitter

Sumber: data diolah penulis

Sementara itu, grafik 4 menunjukan program kampanye yang dinarasikan oleh pasangan calon Idris-Imam di media sosial Twitter melalui akun @idrisimam2020. Program kampanye mengenai ekonomi menempati peringkat pertama dengan persentase $20 \%$. Program kampanye ini menjadi kampanye politik bersifat programatik yang begitu tinggi dikarenakan adanya kebijakan program SUKSES yang ditawarkan oleh pasangan 
calon Idris-Imam apabila terpilih sebagai Wali Kota dan Wakil Wali Kota Depok (lihat Republika, 2020). Isu infrastruktur menempati urutan kedua terkait program kampanye yang sering dinarasikan di Twitter dengan persentase sebesar $18 \%$. Tawaran kebijakan mengenai upaya pemerataan pembangunan dengan memberikan 5 miliar per-kelurahan menjadi salah satu katalisator meningkatnya janji program kampanye mengenai pembangunan infrastruktur (lihat Radar Depok, 2020). Sedangkan isu sosial dan politik sebesar $10 \%$ diperkuat karena adanya program kampanye politik yang melibatkan beberapa kelompok sosial seperti paguyuban, komunitas, dan karang taruna di Kota Depok yang berupaya memenangkan pasangan calon Idris-Imam.

Lebih lanjut, kampanye programatik di media sosial tersebut diharapkan dapat berimplikasi pada mobilisasi massa. Tawaran program dalam kampanye di media sosial oleh masing-masing pasangan calon mempengaruhi para penerima pesan di media sosial untuk memilih pasangan calon yang sesuai dengan preferensi kebijakan persoalan publik di Kota Depok. Sebagaimana fungsi media sosial oleh Andreas Jungherr (2016) mengatakan bahwa, kampanye di media sosial dapat digunakan untuk melakukan mobilisasi dan mengkoordinasikan para pemilih untuk memilih ke bilik suara. Sementara itu, karakteristik kampanye politik yang bersifat programatik menurut Bardhan \& Mookherjee (2018) yakni dapat diverifikasi dan diterima secara publik. Sehingga, fungsi media sosial dalam berkampanye ini dapat dijadikan sarana untuk melihat implikasi kampanye politik programatik menggunakan media sosial Twitter terhadap perolehan suara pasangan calon yang dipilih di bilik suara oleh masyarakat Kota Depok.

Akan tetapi, temuan penulis dalam penelitian ini dengan mengaitkan fungsi media sosial dalam kampanye politik justru tidak serta merta dapat menjadi faktor determinan terhadap perolehan suara pasangan calon. Pasangan calon Pradi Supriatna dan Afifah Alia yang memiliki aktivitas di media sosial Twitter yang begitu tinggi justru tidak mendapatkan perolehan suara yang lebih tinggi dari pasangan calon Mohammad Idris dan Imam Budi Hartono. Perolehan rekapitulasi suara Idris-Imam unggul sebesar 55,55\% dari Pradi-Afifah yang hanya mencatatkan persentase sebesar 44,45\% (lihat Radar Depok, 2020). Ini tentunya menandakan bahwa tingginya aktivitas di Twitter dan masifnya sebaran narasi kampanye politik yang bersifat programatik belum tentu menjadi faktor penentu untuk dipilih oleh masyarakat Kota Depok.

\section{c. Fungsi Media Sosial sebagai Penyebaran Simbol Semiotika Kampanye Politik}

Andreas Jungherr menyebutkan bahwa fungsi media sosial dalam berkampanye adalah menyampaikan simbol retorika tertentu guna menarik dukungan dari publik di dunia digital. Penggunaan narasi yang diidentikan sebagai suatu bentuk simbolik sebagaimana Pierre Bourdieu (2020) dalam bukunya Bahasa dan Kekuasaan Simbolik yang mengutip pandangan Saussure menyatakan bahwa bahasa (teks dan wacana) merupakan sebuah bentuk simbolik. Kekuatan simbolis dapat terjadi 
dan digunakan apabila adanya kerja sama oleh sebagian pihak dalam suatu kondisi tertentu. Pandangan Pierre Bourdieu (2020) penggunaan kekuatan simbolis merupakan reaksi suatu kondisi atau dapat dipergunakan sebagai bentuk perlawanan terhadap kondisi tersebut.

Adanya penggunaan tagar dalam narasi kampanye politik programatik setiap pasangan calon di Twitter juga menunjukan adanya upaya politik dalam penggunaan simbol saat menyampaikan pesan kampanye dalam berupa pemanfaatan semiotika.

Semiotika merupakan ilmu tentang tanda yang dapat memperjelas makna sebuah teks (Lantowa et al., 2017). Penggunaan simbol dalam berupa semiotika oleh pasangan calon di Twitter dimaksudkan juga sebagai upaya memasarkan program kampanye di media sosial dengan tujuan untuk dapat diingat oleh para pengguna Twitter. Penulis mencoba melihat penggunaan tagar politik dalam setiap kampanye politik programatik menggunakan social network analysis (SNA) Nvivo 12 Plus sebagai berikut:

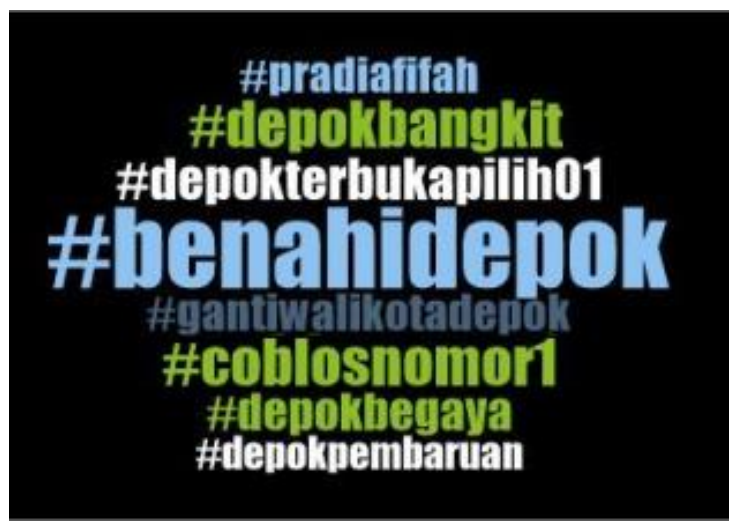

Gambar 2. Tagar Kampanye di Media Sosial Twitter Pradi-Afifah

Sumber: data diolah penulis

Temuan dalam penelitian ini menunjukan penggunaan tagar dalam kampanye pasangan calon Afifah di media sosial Twitter begitu beragam. Tagar tersebut sebagai bagian dari simbolis semiotika memiliki maksud dan tujuan politik tersendiri dalam menyampaikan pesan kampanye. Gambar 1 menunjukan bahwa tagar \#benahidepok paling sering digunakan oleh akun @pradi_afifah di setiap narasi kampanye termasuk narasi kampanye politik programatik di Twitter. Hal itu dicirikan dengan besarnya tagar \#benahidepok di antara beberapa tagar lainnya. Tagar \#benahidepok menunjukan narasi untuk mendapatkan simpati publik dalam memperbaiki segala persoalan yang ada di Kota Depok oleh pasangan calon Pradi-Afifah. Beberapa tagar lainnya seperti \#depokterbukapilih01, \#coblosnomor1, \#depokbangkit, \#depokterbukapilih01,

\#gantiwalikotadepok, \#depokbegaya, \#depokpembaruan, dan \#pradiafifah. Tagar-tagar ini merepresentasikan situasi politik elektoral di Kota Depok yang selama periode Pilkada selalu dimenangi oleh koalisi yang tergabung dengan Partai Keadilan Sejahtera (PKS) (lihat Tirto, 2018).

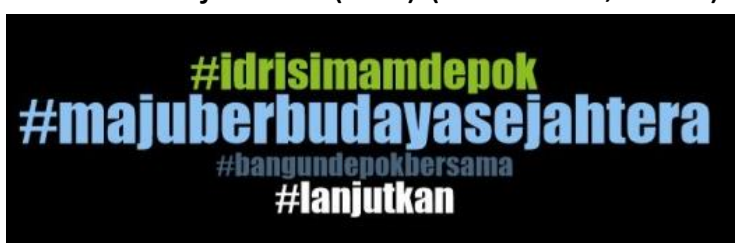

Gambar 3. Tagar Kampanye di Media Sosial Twitter Idris-Imam Sumber: data diolah penulis

Sementara itu, gambar 2 menjelaskan akun pasangan calon Idris-Imam dalam setiap narasi kampanye politik nya juga menggunakan beberapa tagar yang menunjukan simbol semiotika politik dalam meraih dukungan dari media sosial Twitter melalui akun @idrisimam2020. 
Akan tetapi, perbedaannya cukup jelas bahwa pasangan Idris-Imam ini tidak begitu banyak menggunakan tagar dalam setiap narasi kampanyenya dibandingkan dengan pasangan calon Pradi-Afifah. Ada pun tagar yang paling sering muncul ialah \#majuberbudayasejahtera yang ditandai dengan tagar yang paling besar di antara beberapa tagar lainnya. Tagar tersebut merupakan representasi dari visi pasangan calon Idris-Imam yakni "Depok Maju, Berbudaya, Sejahtera" (lihat Kompas, 2020). Beberapa tagar lainnya seperti \#idrisimamdepok, \#bangundepokbersama, dan \#lanjutkan yang merupakan representasi kampanye sebagai posisi petahana.

Maka dari itu, penjelasan mengenai fungsi media sosial sebagai representasi simbolik ditunjukan dengan bentuk semiotika tagar politik yang kerap digunakan sebagai pelengkap narasi kampanye politik programatik masingmasing pasangan calon di Twitter. Penggunaan tagar merupakan bentuk dari ekspresi serta karakter dalam penggunaan media sosial yang bersifat polifonik dan heterogen (Winter \& Lavis, 2020). Tagar juga sebagai bentuk intertekstual sebagai tindakan politik ("hashtag activism") atau bentuk proses literasi. Hal itu dikarenakan tagar dapat mengaitkan sejumlah pandangan di media sosial dengan keterkaitan terhadap satu gagasan kunci yang dijadikan sebagai ruang diskursif yang efektif sebagai dasar tindakan politik (Cahyaningtyas et al., 2021).

\section{Kesimpulan}

Penelitian ini mencoba untuk menjelaskan penggunaan media sosial Twitter sebagai bagian dari kampanye politik programatik pasangan calon menggunakan Social Network Analysis (SNA) Nvivo 12 Plus. Pandangan Andreas Jungherr (2016) mengenai fungsi dari penggunaan media sosial menunjukan bahwa media sosial memiliki peranan penting dalam menyampaikan pesan kampanye politik. Selain itu, kampanye politik programatik yang dijelaskan oleh Bardhan \& Mookherjee (2018) banyak berdasarkan kepada tawaran kebijakan. Ini mengartikan bahwa penggunaan media sosial dapat menjadi sarana untuk menyampaikan informasi mengenai politik programatik kebijakan para pasangan calon.

Temuan dari penelitian ini dalam melihat penggunaan media sosial Twitter sebagai sarana berkampanye meliputi beberapa hal. Pertama, media sosial Twitter dapat memberlangsungkan kampanye politik programatik dengan melihat aktivitas secara rutin akun pasangan calon di setiap minggunya. Aktifnya akun Twitter pasangan calon merupakan bagian dari upaya kampanye politik memperkenalkan serangkaian program yang ditawarkan oleh setiap pasangan calon. Akun @pradi_afifah yang merepresentasikan pasangan calon Pradi Supriatna dan Afifah Alia menjadi akun yang paling aktif di media sosial Twitter dibandingkan dengan akun @idrisimam2020 sebagai representasi dari Mohammad Idris dan Imam Budi.

Kedua, dalam melihat isu dari setiap kampanye politik programatik di Twitter, media sosial Twitter berfungsi sebagai media informasi program setiap pasangan calon. Penulis menemukan setiap pasangan calon memiliki preferensi isu 
kampanye programatik yang menawarkan beberapa kebijakan. Pradi-Afifah melalui akun @pradi_afifah di Twitter memiliki tiga preferensi isu kampanye politik programatik diantaranya kesehatan (18\%), ekonomi (17\%), dan infrastruktur (16\%). Sementara itu, pasangan Idris-Imam memiliki tiga preferensi isu kampanye politik programatik diantaranya ekonomi (20\%), infrastruktur (18\%), dan sosial \& politik (10\%).

Ketiga, penggunaan media sosial sebagai sarana informasi kampanye politik programatik tidak serta merta menjadikan faktor determinan dalam perolehan suara di Kota Depok. Terbukti, kendati pasangan calon Pradi-Afifah dinilai lebih aktif mengampanyekan berbagai program politik yang ditawarkan di Twitter, akan tetapi hal tersebut belum mampu merebut dukungan suara masyarakat untuk memilih pasangan calon tersebut. Sehingga dapat dikatakan bahwa penggunaan media sosial dalam kampanye Pilkada Kota Depok belum sepenuhnya menentukan pemilih untuk memilih melalui program politik pasangan calon.

Keempat, media sosial sebagai fungsi simbolik juga dikaitkan dengan penggunaan tagar dalam setiap narasi kampanye politik programatik pasangan calon di Twitter. Ini menunjukan bahwa penggunaan tagar sebagai simbol semiotika merupakan kumpulan berbagai pandangan menjadi suatu gagasan kunci yang dijadikan sebagai upaya politik. Penulis menemukan bahwa setiap pasangan calon memiliki tagar politik masing-masing di Twitter, baik itu pasangan calon Pradi-Afifah maupun IdrisImam.
Maka dari itu, dapat dikatakan bahwa masing-masing kandidat memfungsikan media sosial Twitter sebagai sarana kampanye politik programatik yang menawarkan kebijakan atas berbagai persoalan di Kota Depok. Tingginya aktivitas kampanye di Twitter tidak serta merta menjadi penentu dalam meraih suara pemilih untuk memilih pasangan calon tersebut. Sehingga rekomendasi penulis untuk penelitian selanjutnya perlu adanya penelitian yang melengkapi kampanye politik programatik dengan penetrasi masyarakat Kota Depok terhadap media sosial tertentu. Hal ini guna melihat faktor lain dari masif dan aktifnya kampanye politik programatik oleh akun media sosial pasangan calon, namun masih belum mendapat perhatian publik untuk memilih pasangan calon tersebut. 


\section{DAFTAR PUSTAKA}

Ardha, B. (2014). Social Media sebagai Media Kampanye Partai Politik 2014 di Indonesia. Jurnal Visi Komunikasi, 13(1), 105-120.

Ayok Jakarta. (2020). Kurangi Macet, Paslon 01 Pilkada Depok Pradi-Afifah Ingin Perlebar Jalan Raya Sawangan.

Ayokjakarta.Com. https://www.ayojakarta.com/read/2020/12/03/27949/kurangi-macet-paslon-01pilkada-depok-pradi-afifah-ingin-perlebar-jalan-raya-sawangan

Bardhan, P., \& Mookherjee, D. (2018). A Theory of Clientelistic Politics Versus Programmatic Politics (No. dp-317).

Bourdieu, P. (2020). Kekuatan Simbolis dan Lapangan Politik. In Bahasa dan Kekuasaan Simbolik (pp. 234-246). IRCiSoD.

Cahyaningtyas, J., Udasmoro, W., \& Sofjan, D. (2021). Pembelajaran Sosial Termediasi dan Aktivisme Media Sosial untuk Pola Hidup Berkelanjutan di Indonesia. Jurnal Komunikasi, 16(1), 1-15.

Carreras, M. (2016). Compulsory Voting and Political Engagement (Beyond the Ballot Box): A Multilevel Analysis. Electoral Studies, 43, 158-168. https://doi.org/10.1016/j.electstud.2016.04.005

Catalinac, A. (2015). From Pork to Policy: The Rise of Programmatic Campaigning in Japanese Elections. The Journal of Politics, 78(1), 1-18. http://dx.doi.org/10.1086/683073

Cheeseman, N., Luna, J. P., Kitschelt, H., Paget, D., Rosenblatt, F., Sample, K., Toro, S., Molleda, J. V., Staak, S. van der, \& Wang, Y. (2014). Politics Meets Policies: The Emergence of Programmatic Political Parties. International IDEA.

Creswell, J. (2016). Research Design: Pendekatan Metode Kualitatif, Kuantitatif, dan Campuran. PUSTAKA PELAJAR.

Diana, S. N. (2017). Identifikasi Pengguna Media Sosial yang Berpengaruh Berdasarkan Graph dengan Metode Social Network Analysis.

Hagar, D. (2014). Campaigning Online: Social Media in the 2010 Niagara Municipal Elections. Canadian Journal of Urban Research, 23(1), 23(1), 74-98.

Hasfi, N., Usman, S., \& Santosa, H. P. (2017). Representasi Kepemimpinan Calon Presiden di Twitter. Jurnal Aspikom, 3(2), 270-284.

Husnulwati, S. (2021). Tinjauan Hukum terkait Kampanye Pilkada di tengah Pandemi Covid-19. Solusi, 19(1).

Jungherr, A. (2016). Four Functions of Digital Tools in Election Campaigns: The German Case. The International Journal of Press/Politics, 21(3), 358-377. https://doi.org/10.1177/1940161216642597

Kitschelt, H, \& Wilkinson, S. I. (Eds.). (2007). Patrons, Clients, and Policies: Patterns of Democratic Accountability and Political Competition. Cambridge University Press.

Kitschelt, Herbert. (1995). Formation of Party Cleavages in Post-Communist Democracies: Theoretical Propositions. Party Politics, 1(4), 447-472. https://doi.org/10.1177/1354068895001004002

Kompas. (2020). Usung Slogan "Depok Maju, Berbudaya, Sejahtera", Ini Misi Idris-IBH di Pilkada

Depok.

Kompas.Com. https://megapolitan.kompas.com/read/2020/09/09/12544751/usung-slogan-depokmaju-berbudaya-sejahtera-ini-misi-idris-ibh-di-pilkada?page=all

Lantowa, J., Marahayu, N. M., \& Khairussibyan, M. (2017). Semiotika: Teori, Metode, dan Penerapannya dalam Penelitian Sastra. Deepublish. 
Lilleker, D. G., \& Koc-Michalska, K. (2017). What Drives Political Participation? Motivations and Mobilization in a Digital Age. Political Communication, 34(1), 21-43.

Mas'udi, W., \& Kurniawan, N. indra. (2017). Programmatic Politics and Voter Preferences: The 2017 Election in Kulon Progo, Yogyakarta. Contemporary South East Asia, 39(3), 449-469. https://doi.org/10.355/cs39-3c

Maulidika, W., \& Agung, E. B. W. (2014). Kampanye Meperbaiki Citra Olahraga Biliard di Indonesia. Jurnal Tingkat Sarjana Bidang Senirupa Dan Desain, 3(1), 180555.

Media Indonesia. (2020). Pradi-Afifah Tawarkan Strategi Pengembangan Ekonomi Depok. Mediaindonesia.Com. https://mediaindonesia.com/megapolitan/366376/pradi-afifahtawarkan-strategi-pengembangan-ekonomi-depok

Nimmo, D. (2010). Komunikasi Politik (5th ed.). PT Remaja Rosdakarya.

Nurjaman, A. (2020). Pilkada Serentak 2020: Menuju Paradigma Baru Model Kampanye di Indonesia. In S. Munawar (Ed.), Pilkada di Masa Pandemi (pp. 105-120). Penerbit Lingkaran.

Radar Depok. (2020). Pemerataan Pembangunan Prioritas Idris-Imam. Radardepok.Com. https://www.radardepok.com/2020/11/pemerataan-pembangunan-prioritas-idrisimam/

Radar Depok. (2020). Pilkada Depok: Idris Imam Juaranya. Radardepok.Com. https://www.radardepok.com/2020/12/pilkada-depok-idris-imam-juaranya/

Republika. (2020). Pasangan Idris-Imam Siapkan "Sukses" untuk Ekonomi Depok. Republika.Co.Id. https://www.republika.co.id/berita/qjmoeu320/pasangan-idrisimamsiapkan-sukses-untuk-ekonomi-depok

Republika. (2020). Pilkada Depok, Pradi-Afifah Ajukan Berobat Gratis Pakai KTP. Republika.Co.Id. https://www.republika.co.id/berita/qk7mr3438/pilkada-depokpradiafifah-ajukan-berobat-gratis-pakai-ktp

Rinaldi, M. R., \& Yuniasanti, R. (2020). Kecemasan pada Masyarakat Saat Masa Pandemi Covid19 di Indonesia. In D. H. Santoso \& A. Santosa (Eds.), Covid-19 dalam Ragam Tinjauan Perspektif (p. 137). MBridge Press.

Setiadi, A. (2016). Pemanfaatan Media Sosial untuk Efektifitas Komunikasi. Cakrawala-Jurnal Humaniora, 16(2).

Tirto. (2018). Takhta PKS yang Langgeng di Depok. Tirto.Id. https://tirto.id/takhta-pks-yanglanggeng-di-depok-cXvS

Williams, C. B. (2017). Introduction: Social media, Political Marketing and the 2016 US Election. Journal of Political Marketing, 16(3-4), 207-211. https://doi.org/10.1080/15377857.2017.1345828

Winter, R., \& Lavis, A. (2020). Looking, But Not Listening? Theorizing the Practice and Ethics of Online Ethnography. Journal of Empirical Research on Human Research Ethics, 15(1-2), 55-62. https://doi.org/10.1177/1556264619857529

Wyatt, A. (2013). Combining Clientelist and Programmatic Politics in Tamil Nadu, South India. Commonwealth \& Comparative Politics, 51(1), 27-55. https://doi.org/10.1080/14662043.2013.749674 